neonatal hepatitis of prenatal onset, and has persisting hepatosplenomegaly. Neonatal hepatitis is associated with $\alpha$-1-antitrypsin deficiency in 10 to $20 \%$ of cases, the majority being homozygous for the $\mathrm{Z}$ allele. The $\mathrm{Z}^{-}$phenotype can be distinguished only by examination of the parental phenotypes.

The occurrence of neonatal hepatitis in our patient suggests that while low levels of plasma antiprotease are a factor in the aetiology of liver damage, such damage can occur without the presence of two $\mathrm{Z}$ alleles. Many individuals deficient in antiprotease activity have normal liver function however, so one or more other factors must be involved.

One may speculate on the nature of the second factor. It is not the PAS-positive deposits. ${ }^{5}$ Their presence and distribution show no correlation with liver damage. The limited family data suggest that $\mathrm{ZZ}$ individuals are at much greater risk of liver damage if a $\mathrm{ZZ}$ sibling has had liver disease, but the observation of monozygotic twins with the $\mathrm{ZZ}$ phenotype being discordant for liver disease is against the second factor being a separate gene defect. ${ }^{6}$ Attempts to identify infective or other environmental agents have not been successful. A further possibility is that low levels of $\alpha-1$-antitrypsin predispose, in some way, to immune damage to the fetal or neonatal liver. This is supported by the observation that lymphocytes from individuals with hepatitis and antiprotease deficiency are cytotoxic for isolated rabbit hepatocytes. ${ }^{7}$ As there is evidence that maternal lymphocytes enter the fetal circulation, ${ }^{8}$ these could become similarly sensitised; this would provide an explanation for the increased incidence of liver damage in $\alpha$-1-antitrypsindeficient individuals whose previous sibling was affected.
We thank Dr D W Hide and Professor Otto Wolff for permission to report this case, Miss P Goffron for preparing the manuscript, and Dr A Milford Ward and the staff of the Supraregional Specific Protein Reference Unit, for performing the $\alpha-1$ antitrypsin electrophoresis and quantitation.

\section{References}

1 Talamo R C, Langley C R E, Reed C E, Makino S. Alpha 1-antitrypsin deficiency: a variant with no detectable alpha 1-antitrypsin. Science $1973 ; 181$ : 70-1.

2 Martin J P, Vandeville D, Ropartz C. Letter: Alpha 1antitrypsin deficiency: PiO. Lancet 1973; ii: 845.

3 Bernheim J L, Arnaud P, Cellier C, Pokroy N, Traeger J. Apparent total alpha 1-antitrypsin deficiency-report of a case. Isr J Med Sci 1976; 12: 678-85.

4 Sveger T. Liver disease in alpha 1-antitrypsin deficiency detected by screening 200,000 infants. N Engl J Med 1976; 294: 1316-21.

${ }^{5}$ Eriksson S, Larsson C, Sveger T. Alpha 1-antitrypsin deficiency and disease. In: Boström $\mathbf{H}$, Ljungstedt $\mathbf{N}$, eds. Congenital diseases in childhood. Medical and sociomedical aspects. Skandia International Symposia; 12. Stockholm: Almqvist \& Wiksell, 1980: 70-91.

- Psacharopoulos H T, Mowat A P, Cook P J L, Rodeck C. Familial factors and the severity of liver disease in genetic deficiency of alpha-1 antitrypsin (PiZZ) (abstract). Arch Dis Child 1981; 56: 803-4.

7 Smith A L, Cochrane A M G, Mowat A P, Eddleston A W L F, Williams R. Cytotoxicity to isolated rabbit hepatocytes by lymphocytes from children with liver disease. J Pediatr 1977; 91 : 584-9.

8 Schroder J. Transplacental passage of blood cells. J Med Genet 1975; 12: 230-42.

Correspondence to Dr John Burn, MRC Clinical Genetics Unit, Institute of Child Health, 30 Guilford Street, London WC1N 1EH.

Received 26 November 1981
SUMMARY About half of all infants and toddlers with infectious diarrhoea of probable virus aetiology and treated with an oral rehydration solution containing $4.6 \%$ glucose had faecal glucose $\geqslant 0.3 \%$. In most of them the faecal concentration of glucose was higher than $0.50 \%$. From the physiological point of view, it seems wise to decrease the glucose concentration substantially from that so often recommended for the treatment of diarrhoea in developed countries.
The use of oral rehydration solutions in the treatment of diarrhoea in infants and toddlers has been successful. The precise composition of an ideal oral fluid is unknown. Solutions with a low glucose (2\%) and a high sodium concentration (about 90 $\mathrm{mmol} / \mathrm{l})$ are recommended for developing countries, but in developed countries such solutions generally contain 4-5\% glucose (or sucrose) and $25-35 \mathrm{mmol} / 1$ sodium. ${ }^{1}$ The higher incidence of toxigenic infections in developing countries is one reason for the difference, but the traditional fear of hyperosmolar 
dehydration and the desire to supply calories are two others. This report deals with the question of the optimal glucose concentration in oral rehydration solutions used for the treatment of infectious diarrhoea in developed countries.

\section{Material and methods}

All children under 4 years of age admitted to our department because of infectious diarrhoea during 1977-79 were initially included. If faecal culture showed growth of enteropathogenic bacteria the children were excluded from the investigation. One child showed growth of the Yersinia sp. organism and another growth of Shigella sp. The first 31 children (series A) were given an oral solution containing $4.6 \%$ glucose $(225 \mathrm{mmol} / \mathrm{l})$, sodium $35 \mathrm{mmol} / \mathrm{l}$, and potassium $20 \mathrm{mmol} / \mathrm{l}$. After 36 hours, increasing quantities of a milk-based formula and decreasing amounts of the initial rehydration solution were given. In the next series (B) alternate children (B-1) were given the same solution, and the others (B-2) a solution containing $2.3 \%$ glucose.

Of the initially randomised children only those in whom there was a watery phase of the stools could be studied. The data of 3 children were too scanty to be included. Eventually therefore group B-1 comprised 20 children, and B-2 16 children. The means and ranges of ages in the three groups were A:15 months (5-44), B-1:16 months (6-31), and B-2:17 months (5-36). Faecal glucose was estimated in the watery phase of the stools provided it was possible to obtain a liquid sample with the aid of Rediatest (BM). Any test showing a ++ reaction or greater $(\geq 0.3 \%$ glucose $)$ was regarded as positive.

\section{Results}

Thirteen of 27 children in the first series had faecal glucose. Of 198 faecal specimens 60 gave positive results. Nine of 20 children in group B-1 had faecal glucose and 31 of 96 specimens were positive for glucose. In group B-2 (the children given a lower concentration of glucose) 6 of 16 had faecal glucose, and 6 out of 65 stools were positive for glucose. There was no significant difference between the groups judged by time for hospital care, oral treatment failures, or number of loose stools per day.

Most of the positive stools showed +++ reactions - that is a glucose concentration of $\geq 0.5 \%$.

In one infant with initial moderate iso-osmolar dehydration oral administration of the $4.6 \%$ solution seemed to cause an aggravated and hyperosmolar dehydration (serum sodium $152 \mathrm{mmol} / \mathrm{l}$ ). In this infant all stools were watery and highly positive for glucose until intravenous treatment with fluids was given.

\section{Discussion}

Stools may occasionally contain traces of glucose. The upper normal limit for faecal glucose has been discussed and a concentration of $\geq 0.25 \%$ is generally regarded as pathogical. ${ }^{2}$ In our study designed for positive stools all the children had faecal glucose in concentrations $\geq 0.3 \%$ most of them above $0.5 \%$. Thus children with 'ordinary Western' infectious diarrhoea may often be affected by temporary glucose malabsorption, and even if solutions of only $2.3 \%$ glucose are used, a few stools of some children may contain glucose above the normal limit.

Most children given 4-5\% glucose solutions seem to tolerate them well. However, the aim of producing a small increase in the caloric supply is probably not achieved if glucose is lost in the stools, and moreover there may be some risk of inducing more diarrhoea. Unlike earlier investigations in piglets and infants, ${ }^{34}$ some recent studies report faecal glucose in virusinduced diarrhoea, especially in rotavirus infection. ${ }^{5}$ Structural and functional changes of the intestinal mucosa indicating impaired glucose absorption have also been shown in virus-induced diarrhoea. ${ }^{6}$

A glucose concentration lower than $4-5 \%$ also seems sufficient from a physiological point of view. Glucose-enhanced sodium and water absorption appears to reach an optimal level at as low a glucose concentration as $1 \%{ }^{78}$

With this report we wish to call in to question the wide difference between the concentration of glucose recommended for developing countries by WHO and that used frequently in developed countries, especially since some of the solutions used in developed countries are also distributed in developing ones.

\section{References}

1 Finberg L. The role of oral electrolyte-glucose solutions in hydration for children-international and domestic aspects. J Pediatr 1980; 96: 51-4.

2 Lifshitz F. Carbohydrate problems in paediatric gastroenterology. Clin Gastroenterol 1977; 6: 415-29.

3 Hamilton $\mathbf{J ~ R}$, Gall D G, Butler D G, Middleton P J. Viral gastroenteritis: recent progress, remaining problems. In: Elliott $\mathrm{K}$, Knight $\mathrm{J}$, eds. Acute diarrhoea in childhood. Ciba Foundation Symposium No 42. Amsterdam: Elsevier/North-Holland, 1976: 209-22.

4 Tallett S, MacKenzie C, Middleton P, Kerzner B, Hamilton R. Clinical, laboratory, and epidemiologic features of a viral gastroenteritis in infants and children. Pediatrics 1977; 60: 217-23.

5 Mäki M. A prospective clinical study of rotavirus 
diarrhoea in young children. Acta Paediatr Scand 1981; 70: 107-13.

- Davidson G P, Barnes G L. Structural and functional abnormalities of the small intestine in infants and young children with rotavirus enteritis. Acta Paediatr Scand 1979; 68: 181-6.

7 Sladen G E, Dawson A M. Interrelationships between the absorptions of glucose, sodium, and water by the normal human jejunum. Clin Sci 1969; 36: 119-32.
8 Sladen G E. A review of water and electrolyte transport. In: Burland W L, Samuel P D, eds. Transport across the intestine. Edinburgh: Churchill Livingstone, 1972: 14-34.

Correspondence to Dr E Ronge, Department of Paediatrics, Karnsjukhuset, S-541 85 Skovde, Sweden.

Received 23 November 1981

\title{
HLA typing as a method of genetic counselling in congenital adrenal hyperplasia
}

\author{
M O SAVAGE, H FIELD, E WOLF, M E PEMBREY, AND D B GRANT
}

The Hospital for Sick Children; Mothercare Unit of Paediatric Genetics, Institute of Child Health; Department of Diabetes and Immunogenetics, The Medical Unit, St Bartholomew's Hospital, London

SUMMARY A Turkish Cypriot family with 3 consanguineous marriages is described. Segregation of the 21-hydroxylase deficiency gene was traced by HLA genotyping and this information used for genetic counselling.

Close linkage between the 21-hydroxylase deficiency gene and the HLA complex on chromosome 6 has now been established. ${ }^{12}$ Two genes are thought to be concerned in the genetic control of this condition, one between the HLA B and DR loci and a second between the DR and GLO loci. ${ }^{3}$ Before the recognition of the HLA linkage of this enzyme deficiency, detection of heterozygote carriers by measurement of the response of plasma $17 \mathrm{OH}$-progesterone to adrenocorticotrophic hormone (ACTH) stimulation was described. ${ }^{4}$ Comparison of HLA genotyping and ACTH stimulation as methods for detection of heterozygotes has suggested that the former was more reliable because of overlap in plasma $17 \mathrm{OH}$ progesterone levels between obligate heterozygotes and homozygous normal family members, making classification of some family members difficult. ${ }^{5} \mathrm{We}$ describe a family with 3 consanguineous marriages in which segregation of the 21-hydroxylase deficiency gene was traced by HLA typing, and this information used for genetic counselling.

\section{Patients and methods}

The propositus was the first child of Turkish Cypriot parents who were 1st cousins. Ambiguous external genitalia were present at birth and the infant was thought to be a boy with perineal hypospadias and undescended testes. Aged 3 weeks, investigations for poor weight gain showed plasma sodium $124 \mathrm{mmol} / \mathrm{l}$, potassium $9.5 \mathrm{mmol} / \mathrm{l}$, and a karyotype of $46 \mathrm{XX}$. Plasma 17OH-progesterone measured by radioimmunoassay was greatly raised at $2370 \mathrm{nmol} / 1$ (normal range $<10 \mathrm{nmol} / \mathrm{l})$. These features are consistent with the salt-losing form of 21-hydroxylase deficiency. The infant was brought up as a girl.

The family history showed that the pedigree (Figure) contained two other 1st-cousin marriages and that several siblings of both parents had died unexpectedly in infancy in Cyprus. After explanation of the genetic nature of the condition to the parents, the family requested genetic counselling. Accordingly, HLA genotyping of the propositus and 12 other family members who were clinically normal was carried out.

HLA genotyping. Typing for HLA A, B, and C loci was performed by a microlymphocytoxicity test using a modified NIH technique. ${ }^{6}$ HLA-DR antigens were defined on unseparated peripheral blood lymphocytes using a double colour immunofluorescent technique. ${ }^{7}$ All A, B, C, and DR antigens which were officially recognised by the WHO nomenclature committee in 1980 were typed for.

\section{Results}

The results of HLA genotyping are shown in the Figure. As far as can be judged there had been no recombination in the major histocompatability complex, the 5 haplotypes in this family being inherited unchanged.

One of the predictions for the propositus born of 1st cousins was that she would probably be homozygous for an ancestral HLA-haplotype, which is 